\title{
LOGIKA FUZZY DALAM PENENTUAN PUNCAK PANDEMI COVID- 19 BERDASARKAN PEMBERLAKUAN PHYSICAL DISTANCING DAN KUANTITAS CUCI TANGAN
}

\author{
${ }^{1}$ Nouri Alfin Nabilah, ${ }^{2}$ Shinta Aktelia Devin, ${ }^{3}$ Mohammad Mukhlis \\ ${ }^{1,2,3}$ Program Studi Tadris Matematika Institut Agama Islam Negeri Jember \\ Jalan Mataram No.1, Karang Miuwo, Mangli, Kec. Kaliwates, Kab. Jember, Jawa Timur 68136 \\ Email: ${ }^{1}$ nourialfin@gmail.com ${ }^{2}$ shinta.akteliadev@gmail.com
}

\begin{abstract}
Abstrak
COVID-19 (Corona Virus Desease-19) adalah nama resmi peyakit yang sedang mewabah secara global saat ini. Langkah-langkah pencegahan untuk mengurangi kemungkinan infeksi ini termasuk menjaga kontak fisik (physical distancing) dan sering mencuci tangan dengan sabun dan air. Penelitian ini menggunakan pendekatan kualitatif dengan jenis penelitian aksperimen menggunakan tahapan yang telah ditentukan. Dalam penelitian ini akan digunakan Logika Fuzzy (fuzzy logic) dengan metode Tsukamoto, yakni dicari dengan cara mengubah input (berupa himpunan fuzzy yang diperoleh dari komposisi aturan-aturan fuzzy) menjadi suatu bilangan pada domain himpunan fuzzy tersebut. Panelitian ini bertujuan untuk memprediksi kapan terjadinya puncak pandemi COVID-19 dengan memperhatikan langkah pencegahan yakni awal dimulainya kebijakan pemberlakuan physical distancing dan kuantitas masyarakat dalam mencuci tangan. Hasil dari penelitian ini menunjukkan bahwa apabila pemberlakuan physical distanting dan kuantitas cuci tangan dilakukan secara baik dan seimbang maka maka puncak pandemi akan berlangsung pada tanggal 15 April 2020 dan rentang waktu tersebut termasuk terjadi secara cepat.
\end{abstract}

Kata Kunci: Kuantitas Cuci Tangan, Logika Fuzzy, Physical Distancing, Puncak Pandemi COVID-19

\begin{abstract}
Covid-19 (Corona Virus Desease-19) is the official name of the disease that is currently globally. The prevention steps to reduce the possibility of this infection include maintaining physical distancing and frequent hand washing with soap and water. The method used in this study is the experimental method with a predetermined steps. This study will be used the Fuzzy Logic with the Tsukamoto method, which is change the input (in the form of a fuzzy set obtained from the composition of fuzzy rules) to a number in the fuzzy set domain. This study aims to predict when the peak of the Covid-19 pandemic by taking into account the preventive measures, that is the beginning of the physical distancing policy and the quantity of the community in hand washing. The results of this study indicate that if the physical distancing policy and the quantity of hand washing is well done and balanced, the peak of the pandemic will take place on April 15, 2020 and the time includes rapidly.
\end{abstract}

Keywords: Frequent Hand Washing, Fuzzy Logic, Physical Distancing, The Peak of The Pandemic

\section{PENDAHULUAN}

Pada awal tahun 2020, dunia dikejutkan dengan wabah virus corona atau COVID-19 yang menginfeksi hampir seluruh dunia. Semenjak Januari 2020, WHO telah menyatakan dunia masuk ke dalam kondisi darurat global terkait COVID-19 ini (Sebayang, 2020). Pada 30 Januari 2020 virus ini telah menyebar ke lebih dari 20 negara di dunia (Smith, 2020). Khusus di Indonesia sendiri, pemerintah telah mengeluarkan status darurat bencana terhitung 
mulai tanggal 29 Februari 2020 hingga 29 Mei 2020 terkait pandemi virus ini dengan jumlah waktu 91 hari (Buana, 2020).

Corona Virus Desease (Covid) ini pertama kali ditemukan di Wuhan, Tiongkok pada bulan Desember 2019. COVID-19 dapat menyebar dari percikan-percikan yang berasal dari hidung (bersin) ataupun mulut yang keluar dari orang yang terjangkit COVID-19 dan jatuh ke permukaan benda dan sekitarnya. Orang yang setelah menyentuh benda atau permukaan tersebut dan menyentuh mata, hidung atau mulutnya, maka dapat terjangkit COVID-19. Penularan COVID-19 juga dapat terjadi jika orang menghirup percikan yang keluar dari batuk ataupun bersin dari orang yang terjangkit COVID-19.

Ada satu hal yang sangat sederhana yang bisa kita lakukan dan diharapkan berhasil untuk mencegah laju penyebaran yakni : jaga jarak sosial (social distancing), jarak sosial ini dapat diartikan dengan menahan diri untuk menjauhi kerumunan dan membatasi keinginan untuk keluar rumah tanpa keperluan yang penting (Nuraini, 2020). Menjaga jarak sosial merupakan faktor utama untuk mengurangi kontak antar orang. Menjaga kebersihan merupakan faktor kedua untuk mengurangi resiko perpindahan virus dari kontak yang telah dilakukan (Dalton, 2020). Kontak sosial secara kritis menentukan penyebaran infeksi ditengah keadaan saat ini yang belum ada vaksin, hal yang dapat dilakukan adalah melalui kontrol sosial berskala besar dengan menjagak jarak sosial merupakan cara yang paling efektif (Singh, 2020). Keefektifan dan sosialisi mengenai dampak wabah ini serta cara menjaga jarak sosial bergantung pada kredibilitas kesehatan masyarakat, pihak berwenang, pemimpin pemerintahan, dan institusi terkait (The Lancet, 2020). Setelah social distancing mulai populer dan dipraktekkan oleh masyarakat, WHO mengubah penggunaan istilah social distancing dengan physical distancing. Physical distancing ini lebih merujuk pada tindakan menjaga jarak fisik antara satu orang dengan orang lain. Alasan WHO mengganti istilah tersebut salah satunya agar setiap orang bisa saling menguatkan dan berhubungan satu sama lain, meski secara fisik tidak bisa berdekatan. Alasan lain dari penggunaan istilah ini juga mengingat bahwa kesehatan mental seseorang yang tidak kalah penting dengan kesehatan fisik.

COVID-19 dinyatakan telah masuk ke Indonesia sejak akhir Januari 2020, ini dilihat dari data laporan pelayanan kesehatan masyarakat yang terjadi karena terdapat pasien dengan gejala kasus COVID-19. Jumlah pasien semakin bertambah di setiap harinya, hal ini mengindikasikan adanya pola perilaku masyarakat yang masih banyak menyimpang dari kebijakan pemerintah, mulai dari anjuran berdiam diri di rumah, rajin mencuci tangan, dan

Logika fuzzy dalam penentuan puncak pandemi covid-19 berdasarkan pemberlakuan physical distanting dan kuantitas cuci tangan Nabilah, Devin, Mukhlis 
menerapkan segala bentuk pencegahan penularan virus ini. Dengan demikian akan semakin menambah jumlah pasien yang pada akhirnya akan mencapai puncak pandemi dengan jumlah kasus yang paling banyak. Untuk meemprediksi terjadinya puncak pandemi COVID-19 ini dapat dijabarkan serta diperhitungkan dengan menggunakan logika fuzzy dan tahapan pada metode tsukamoto.

Logika fuzzy merupakan sebuah logika yang memiliki nilai kekaburan atau kesamaran antara benar dan salah. Dalam teori logika fuzzy sebuah nilai bisa bernilai benar dan salah secara bersamaan namun berasa besar kebenaran dan kesalahan suatu nilai tergantung kepada bobot keanggotaan yang dimilikinya (Fahmiyanto, 2018). Teori himpunan fuzzy merupakan kerangka matematis untuk mempresentasikan ketidakpastian, ketidakjelasan, ketidaktepatan, kekurangan informasi dan kebenaran parsial (Romi,). Pada penelitian ini kami menggunakan metode Tsukamoto karena metode ini memiliki toleransi terhadap data-data yang tidak tepat dan mudah untuk dimengerti. Pada metode Tsukamoto, setiap aturan dipresentasikan menggunakan himpunan-himpunan fuzzy, dengan fungsi keanggotaan yang monoton.

Tujuan utama dari penelitian ini untuk mengetahui kapan terjadinya puncak pandemi COVID-19 dengan menggunakan logika fuzzy berdasarkan pemberlakuan physical distancing dan kualitas cuci tangan dengan menggunakan motode Tsukamoto.

\section{METODE PENELITIAN}

Penelitian ini menggunakan pendekatan kualitatif dengan jenis penelitian eksperimen, dengan tahapan penelitian sebagai berikut (Wibowo, 2015):

1. Pengumpulan Data

Pengumpulan data merupakan langkah awal pada suatu penelitian. Data yang digunakan pada penelitian ini didapatkan dari mencari informasi awal mengenai penelitian-penelitian yang pernah dilaksanakan sebelumnya, yang berhubungan dengan logika fuzzy dan informasi tentang pandemi COVID-19. Selain itu juga melalui studi literatur, dipelajari teori-teori yang berhubungan dengan logika, dasar matematika, dan khususnya tentang penggunaan metode fuzzy dalam penentuan puncak pandemi COVID-19. Sumbernya berupa buku, jurnal, paper, maupun situs internet yang berhubungan dengan logika fuzzy.

2. Pengolahan Awal

Pengolahan awal (Preprocessing) merupakan tahap untuk mempersiapkan data yang telah diperoleh dari tahap pengumpulan data, yang akan digunakan pada tahap selanjutnya. Dalam penelitian ini pengolahan awal berupa penentuan variabel input yakni pemberlakuan physical distancing dan kuantitas cuci tangan, sedangkan variabel 
outputnya yakni penentuan puncak pandemi COVID-19. Variabel pemberlakuan physical distancing adalah tingkat keefektifitasan penerapan kebijakan physical distancing oleh masyarakat yang mempunyai nilai linguistik kurang dan baik. Variabel kuantitas cuci tangan adalah seberapa sering masyarakat mencuci tangan yang mempunyai nilai linguistik kurang dan baik. Variabel penentuan puncak pandemi COVID-19 adalah proses terjadinya pandemi COVID-19 mencapai puncak dengan korban paling banyak yang mempunyai nilai linguistik lambat dan cepat.

3. Eksperimen dan Pengujian

Tahapan ini akan membahas tahapan penelitian dan teknik pengujian yang akan digunakan. Dalam penelitian ini digunakan logika fuzzy dengan metode tsukamoto untuk menentukan puncak pandemi COVID-19.

4. Evaluasi dan Validasi Penelitian

Tahapan ini akan membahas hasil evaluasi dari eksperimen yang telah digunakan.

Selain itu, pada penelitian ini menggunakan logika fuzzy dengan metode tsukamoto sebagai teknik analisis datanya.

\section{A. Logika Fuzzy}

Dalam penelitian ini akan digunakan Logika Fuzzy (fuzzy logic). Logika fuzzy pertama kali diperkenalkan oleh Prof. Lotfi A. Zadeh pada tahun 1965. Dasar logika fuzzy adalah teori himpunan fuzzy dengan peranan derajat keanggotaan sebagai penentu keberadaan elemen dalam suatu himpunan sangatlah penting (Abidah, 2016). Logika fuzzy menyediakan suatu cara untuk merubah pernyataan linguistik menjadi suatu numerik, misalkan besaran kecepatan laju kendaraan yang diekspresikan dengan pelan, agak cepat, dan sangat cepat (Ayuningtias, 2017). Logika fuzzy adalah suatu cara yang tepat untuk memetakan suatu ruang input kedalam suatu ruang output, dinyatakan dalam derajat dari suatu keanggotaan dan derajat dari kebenaran (Abidah, 2016). Teori himpunan fuzzy merupakan kerangka matematis untuk mepresentasikan ketidakpastian, ketidakjelasan, ketidaktepatan, kekurangan informasi, dan kebenaran parsial (Kusumadewi, 2006). Konsep matematis yang mendasari panalaran fuzzy sangat sederhana dan mudah dimengerti, fleksibel, memiliki toleransi terhadap data-data yang tidak tepat, mampu memodelkan fungsi-fungsi nonlinier yang sangat kompleks, dapat membangun dan mengaplikasikan pengalaman-pengalaman para pakar secara langsung tanpa harus melalui proses pelatihan (Wibowo, 2015).

Logika fuzzy dalam penentuan puncak pandemi covid-19 berdasarkan pemberlakuan physical 


\section{B. Motode Tsukamoto}

Pada metode Tsukamoto, setiap aturan direpresentasikan menggunakan himpunan himpunan fuzzy, dengan fungsi keanggotaan yang monoton. Untuk menentukan nilai output crisp/hasil yang tegas $(\mathrm{Z})$ dicari dengan cara mengubah input (berupa himpunan fuzzy yang diperoleh dari komposisi aturan-aturan fuzzy) menjadi suatu bilangan pada domain himpunan fuzzy tersebut. Cara ini disebut dengan metode defuzzikasi (penegassan). Metode defuzzikasi yang digunakan dalam metode Tsukamoto adalah metode defuzzikasi rata-rata terpusat (Center Average Defuzzyfier). Setiap konsekuen pada aturan yang berbentuk IF-Then harus direpresentasikan dengan suatu himpunan fuzzy dengan fungsi keanggotaan yang monoton. Sebagai hasilnya, output hasil inferensi dari tiap-tiap aturan diberikan secara tegas (crisp) berdasarkan $\alpha$-predikat (fire strength). Hasil akhirnya diperoleh dengan menggunakan rata-rata terbobot (Kaswidjanti, 2014).

Misalkan ada 2 variabel input, Var-1 (x) dan Var-2 (y), serta 1 variabel output, Var-3 (z), dimana Var-1 terbagi atas 2 himpunan yaitu A1 dan A2 terbagi atas 2 himpunan B1 dan B2, Var-3 juga terbagi atas 2 himpunan yaitu $\mathrm{C} 1$ dan $\mathrm{C} 2$ (C1 dan $\mathrm{C} 2$ harus monoton). Ada aturan yang digunakan (Yuniardi), yaitu:

[R1] IF ( $\mathrm{x}$ is A1) and ( $\mathrm{y}$ is $\mathrm{B} 2)$ THEN ( $\mathrm{z}$ is $\mathrm{C} 1$ )

[R2] IF ( $\mathrm{x}$ is A2) and ( $\mathrm{y}$ is $\mathrm{B} 1$ ) THEN ( $\mathrm{z}$ is $\mathrm{C} 2$ )

Dalam inferensinya, metode Tsukamoto menggunakan tahapan berikut (Ula, 2014):

1. Momodelkan variabel fuzzy (Fuzzyfikasi)

2. Pembentukan basis pengetahuan Fuzzy (Rule dalam bentuk If .... THEN) dan aturan inferensi, menggunakan fungsi implikasi MIN untuk mendapatkan nilai $\alpha$-predikat tiap-tiap rule $(\alpha 1, \alpha 2, \alpha 3, \ldots, \alpha n)$ kemudian masing-masing nilai $\alpha$-predikat ini digunakan untuk menghitung keluaran hasil inferensi secara tegas (crisp) masingmasing rule $(\mathrm{z} 1, \mathrm{z} 2, \mathrm{z} 3, \ldots, \mathrm{zn})$

3. Defuzzyfikasi menggunakan metode rata-rata (Average)

$z=\frac{\sum a_{i} z_{i}}{\sum z}$

Keterangan:

$\mathrm{Z}=$ Variabel output

$\alpha \mathrm{i}=$ Nilai $\alpha$ predikat

zi = Nilai variabel output 


\section{HASIL DAN PEMBAHASAN}

\section{A. Perhitungan Fuzzy}

Asumsikan bahwa pemerintah menentukan pemberlakuan kebijakan melakukan physical distancing dan membiasakan cuci tangan pada tanggal 1 April 2020.

Kemudian merubah pernyataan linguistik menjadi numerik :

Tabel 1. Data Physical Distancing, Kuantitas Cuci Tangan dan Puncak Pandemi COVID-19

\begin{tabular}{c|l|l}
\hline \multicolumn{1}{c|}{ Variabel } & Himpunan & \multicolumn{1}{c}{ Nilai Fuzzy } \\
\hline \multirow{2}{*}{ Physical Distancing } & Kurang & $2,3,4,5$ \\
\cline { 2 - 3 } & Baik & $6,7,8,9,10$ \\
\hline \multirow{2}{*}{ Kuantitas Cuci Tangan } & Kurang & $2,3,4,5$ \\
\cline { 2 - 3 } & Baik & $6,7,8,9,10$ \\
\hline \multirow{2}{*}{ Puncak Pandemi COVID-19 } & Lambat & $16,17,18,19,20,21,22,23,24,25,26,27,28,29,30$ \\
\cline { 2 - 3 } & Cepat & $1,2,3,4,5,6,7,8,9,10,11,12,13,14,15$ \\
\hline
\end{tabular}

Bagaimana Puncak Pandemi COVID-19 jika diketahui :

Physical Distancing $=9$

Kuantitas Cuci Tangan $=8$

Aturan :

1. IF physical distancing kurang AND kuantitas cuci tangan kurang THEN puncak pandemi COVID-19 lambat

2. IF physical distancing kurang AND kuantitas cuci tangan baik THEN puncak pandemi COVID-19 cepat

3. IF physical distancing baik AND kuantitas cuci tangan kurang THEN puncak pandemi COVID-19 lambat

4. IF physical distancing baik AND kuantitas cuci tangan baik THEN puncak pandemi COVID-19 cepat

Penyelesaian menggunakan metode Tsukamoto (Model base Tsukamoto) :

1) Memodelkan variabel fuzzy (Fuzzyfikasi)

a) Variabel Physical Distancing

Variabel Physical Distancing terdiri dari dua himpunan fuzzy yaitu KURANG dan BAIK.

Fungsi keanggotaan Physical Distancing direpresentasikan pada Gambar 1. 


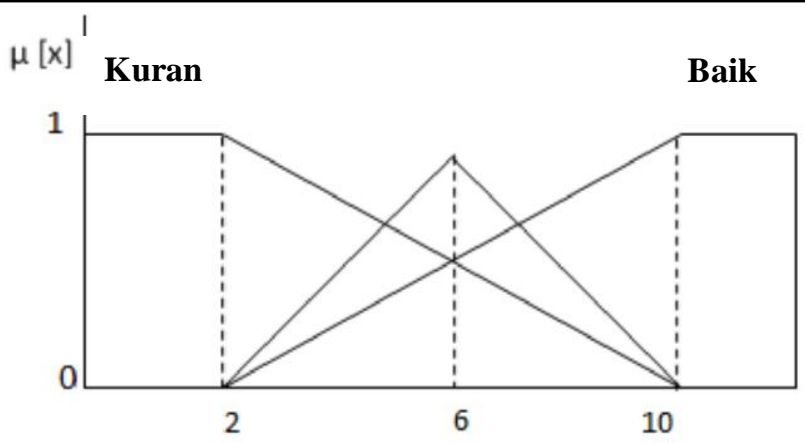

Gambar 1. Fungsi keanggotaan Physical Distancing

Fungsi keanggotaan himpunan KURANG dan BAIK dari variabel Physical Distancing :

$\mu$ Physical Distancing Kurang $[x]=\left\{\begin{aligned} 1, & x \leq 2 \\ \frac{10-x}{10-2,} & 2 \leq x \leq 10 \\ 0, & x \geq 10\end{aligned}\right.$

$\mu$ Physical Distancing Baik $[x]=\left\{\begin{aligned} 1, & x \leq 2 \\ \frac{x-2}{10-2,} & 2 \leq x \leq 10 \\ 0, & x \geq 10\end{aligned}\right.$

Nilai Keanggotaan himpunan KURANG dan BAIK dari variabel Physical Distancing dapat dicari dengan :

$\mu$ Physical Distancing Kurang [9] $=\frac{10-9}{10-2}=0,125$

$\mu$ Physical Distancing Baik $[9]=\frac{9-2}{10-2}=0,875$

b) Variabel Kuantitas Cuci Tangan

Variabel Kuantitas Cuci Tangan terdiri dari dua himpunan fuzzy yaitu KURANG dan BAIK.

Fungsi keanggotaan Kuantitas Cuci Tangan direpresentasikan pada Gambar 2.

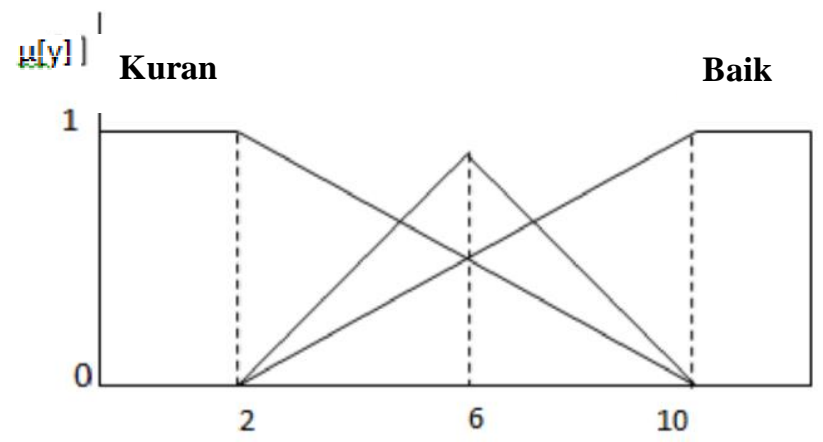

Gambar 2. Fungsi keanggotaan Kuantitas Cuci Tangan

Fungsi keanggotaan himpunan KURANG dan BAIK dari variabel Kuantitas Cuci Tangan : 
$\mu$ Kuantitas Cuci Tangan Kurang $[y]=\left\{\begin{aligned} 1, & x \leq 2 \\ \frac{10-y}{10-2}, & 2 \leq x \leq 10 \\ 0, & x \geq 10\end{aligned}\right.$

$\mu$ Kuantitas Cuci Tangan Baik $[y]=\left\{\begin{aligned} 1, & x \leq 2 \\ \frac{y-2}{10-2}, & 2 \leq x \leq 10 \\ 0, & x \geq 10\end{aligned}\right.$

Nilai Keanggotaan himpunan KURANG dan BAIK dari variabel Kuantitas Cuci Tangan dapat dicari dengan :

$\mu$ Kuantitas Cuci Tangan Kurang [8] $=\frac{10-8}{10-2}=0,25$

$\mu$ PKuantitas Cuci Tangan Baik $[8]=\frac{8-2}{10-2}=0,75$

2) Pembentukan basis pengetahuan Fuzzy (Rule dalam bentuk IF...THEN) dan aturan inferensi

a) IF physical distancing kurang AND kuantitas cuci tangan kurang THEN puncak pandemi COVID-19 lambat

$\alpha 1=\mu$ Physical Distancing Kurang $\cap \mu$ Kuantitas Cuci Tangan Kurang

$=\min$ ( $\mu$ Physical Distancing Kurang [9]; $\mu$ Kuantitas Cuci Tangan Kurang [8])

$=\min (0,125 ; 0,25)$

$=0,125$

$\mathrm{z} 1=30-0,125(30-1)$

$=30-0,125(29)$

$=26,375$

b) IF physical distancing kurang AND kuantitas cuci tangan baik THEN puncak pandemi COVID-19 cepat

$\alpha 2=\mu$ Physical Distancing Kurang $\cap \mu$ Kuantitas Cuci Tangan Baik

$=\min (\mu$ Physical Distancing Kurang [9]; $\mu$ Kuantitas Cuci Tangan Baik [8])

$=\min (0,125 ; 0,75)$

$=0,125$

$\mathrm{z} 2=30-0,125(30-1)$

$=30-0,125(29)$

$=26,375$

c) IF physical distancing baik AND kuantitas cuci tangan kurang THEN puncak pandemi COVID-19 lambat

$\alpha 3=\mu$ Physical Distancing Baik $\cap \mu$ Kuantitas Cuci Tangan Kurang

$=\min (\mu$ Physical Distancing Baik [9]; $\mu$ Kuantitas Cuci Tangan Kurang [8])

$=\min (0,875 ; 0,25)$

$=0,25$

Logika fuzzy dalam penentuan puncak pandemi covid-19 berdasarkan pemberlakuan physical distanting dan kuantitas cuci tangan Nabilah, Devin, Mukhlis 
$\mathrm{z} 3=30-0,25(30-1)$

$=30-0,25(29)$

$=22,75$

d) IF physical distancing baik AND kuantitas cuci tangan baik THEN puncak pandemi COVID-19 cepat

$\alpha 4=\mu$ Physical Distancing Baik $\cap \mu$ Kuantitas Cuci Tangan Baik

$=\min$ ( $\mu$ Physical Distancing Baik [9]; $\mu$ Kuantitas Cuci Tangan Baik [8])

$=\min (0,875 ; 0,75)$

$=0,75$

$\mathrm{z} 4=30-0,75(30-1)$

$=30-0,75(29)$

$=8,25$

3) Defuzzyfikasi Menggunakan metode rata-rata (Average)

$\mathrm{z}=\frac{(\alpha 1 \times \mathrm{z} 1)+(\alpha 2 \times \mathrm{z} 2)+(\alpha 3 \times \mathrm{z} 3)+(\alpha 4 \times \mathrm{z} 4)}{\alpha 1+\alpha 2+\alpha 3+\alpha 4}$

$=\frac{(0,125 \times 26,375)+(0,125 \times 26,375)+(0,25 \times 22,75)+(0,75 \times 8,25)}{0,125+0,125+0,25+0,75}$

$=\frac{(3,296875)+(3,296875)+(5,6875)+(6,1875)}{1,25}$

$=\frac{18,46875}{1,25}$

$=14,775$

Dari keempat aturan yang telah dibentuk maka hasil perhitungan fuzzy menunjukkan bahwa bila pemerintah menerapkan pemberlakuan kebijakan physical distancing dan kuantitas cuci tangan pada tanggal 1 April 2020, maka :

1. Jika physical distancing dilakukan secara kurang maksimal dan kuantitas cuci tangan kurang maksimal, maka puncak pandemi akan terjadi secara lambat yakni pada tanggal 26 April 2020.

2. Jika physical distancing dilakukan secara kurang maksimal dan kuantitas cuci tangan baik/maksimal, maka puncak pandemi akan terjadi secara lambat yakni pada tanggal 26 April 2020.

3. Jika physical distancing dilakukan secara baik/maksimal dan kuantitas cuci tangan kurang maksimal maka puncak pandemi akan terjadi secara lambat yakni pada tanggal 23 April 2020.

4. Jika physical distancing dilakukan secara baik/maksimal dan kuantitas cuci tangan baik/maksimal maka puncak pandemi akan terjadi secara cepat yakni pada tanggal 8 April 2020. 
Dari aturan-aturan tersebut didapatkan hasil bahwa apabila physical distancing dan kuantitas cuci tangan dilakukan secara seimbang, maka puncak pandemi akan terjadi pada tanggal 15 April 2020 dan waktu rentang waktu tersebut termasuk terjadi secara cepat.

\section{SIMPULAN DAN SARAN}

Logika fuzzy dapat digunakan dalam memprediksi suatu kejadian atau suatu hal, dan metode tsukamoto merupakan salah satu metode yang dapat digunakan dalam perhitungan nilai fuzzy. Dengan merubah informasi linguistik menjadi numerik maka logika fuzzy bisa dilakukan dengan baik. Pada penelitian ini didapatkan bahwa apabila physical distancing dan kuantitas cuci tangan dilakukan secara seimbang maka puncak pandemic akan terjadi pada tanggal 15 April 2020 dan waktu rentang waktu tersebut termasuk terjadi secara cepat. Hal ini tidak terlepas dari perhitungan matematika dengan mempertimbangkan variabel yang diuji (physical distancing dan kuantitas cuci tangan) serta tanpa mempertimbangkan faktor lain yang dapat mempengaruhi terjadinya puncak pandemi seperti ketersediaan APD (Alat Pelindung Diri), jumlah tenaga medis, ketersediaan pangan, sektor ekonomi, dan lain sebagainya.

\section{DAFTAR PUSTAKA}

Books:

Kusumadewi, S. (2006) Logika Fuzzy. Yogyakarta: Graha Ilmu.

\section{Online journal:}

Abidah, Siti. (2016) Analisis Komparasi Metode Tsukamoto dan Sugeno dalam Prediksi Jumlah Siswa Baru. Journal Speed. Volume 8. № 2.

Ayuningtias, Laras Purwati, dkk. (2017) Analisa Perbandingan Logic Fuzzy Metode Tsukamoto, Sugeno, Dan Mamdani (Studi Kasus : Prediksi Jumlah Pendaftar Mahasiswa Baru Fakultas Sains Dan Teknologi Universitas Islam Negeri Sunan Gunung Djati Bandung). Jurnal Teknik Informatika. Vol. 10 No. 1.

Buana, Dana Riksa. (2020) Analisis Perilaku Masyarakat Indonesia dalam Menghadapi Pandemi Virus Corona (Covid-19) dan Kiat Menjaga Kesejahteraan Jiwa. Jurnal SALAM; Jurnal Sosial \& Budaya Syar-i. Vol. 7 No. 3. 
Dalton, Craig B. (2020) Pre-emptive low cost social distancing and enhanced hygiene implemented before local COVID-19 transmission could decrease the number and severity of cases. The Medical Journal of Australia.

Fahmiyanto, Ekajaya, dkk. (2018) Diagnosis Penyakit THT Menggunakan Metode Fuzzy Tsukamoto Berbasis Android. Jurnal Pengembangan Ilmu Informasi dan Ilmu Komputer. Vol.2 No.8

Kaswidjanti, Wilis, dkk. (2014) Implementasi Fuzzy Inference System Metode Tsukamoto Pada Pengambilan Keputusan Pemberian Kredit Pemilikan Rumah. Jurnal TELEMATIKA Vol. 10. No. 2.

Smith, A. Wilder. (2020) Isolation, quarantine, social distancing and community containment: pivotal role for old-style public health measures in the novel coronavirus (2019-nCoV) outbreak. Journal of Travel Medicine. doi: 10.1093/jtm/taaa020.

Ula, Mutammimul. (2014) Implementasi Logika Fuzzy Dalam Optimasi Jumlah Pengadaan Barang Menggunakan Metode Tsukamoto (Studi Kasus : Toko Kain My Text). Jurnal ECOTIPE. Volume 1, No.2

Wibowo, Setyoningsih. (2015) Penerapan Logika Fuzzy Dalam Penjadwalan Waktu Kuliah. Jurnal Informatika UPGRIS. Volume 1.

\section{Theses, Dissertation:}

Noname. (2020) Arti Social Distancing dan Physical Distancing, Apa Bedanya?. Diunduh dari http://www.indozone.id/amp/WYsAgk/perbedaan-social-distancing-dan-physicaldistancing

Noname. (2020) Ini Bukti Data Kasus Corona Masuk Indonesia Sejak Akhir Januari 2020. Diunduh dari http://m.kumparan.com/amp/kumparansains/ini-bukti-data-kasus-coronamasuk-indonesia-sejak-akhir-januari-2020-1tGkxlsKap

Nuraini, Nuning. (2020) Data dan Simulasi COVID-19 dipandang dari Pendekatan Model Matematika. Pusat Pemodelan Matematika dan Simulasi - ITB. KK Matematika Industri dan Keuangan - FMIPA - ITB.

Sebayang, R. (2020) Awas! WHO Akhirnya Tetapkan Corona Darurat Global. CNBC Indonesia. Diunduh dari http://cnbcindonesia.com/news/20200131060854-4134146/awas-who-akhirnya-tetapkan-corona-darurat-global

Singh, Rajesh. (2020) Age-structured impact of social distancing on the COVID-19 epidemic in India. DAMTP, Centre for Mathematical Sciences, University of Cambridge, Wilberforce Road, Cambridge CB3 0WA, UK. 
The Lancet. (2020) Scientific and ethical basis for social-distancing interventions against COVID-19. www.thelancet.com/infection dalam https://doi.org/10.1016/S14733099(20)30190-0.

Yuniardi, Romi. Perancangan Sistem Pendukung Keputusan Untuk Menentukan Kelayakan Pemberian Pembiayaan Nasabah Baitul Maalwat-Tamwil (BMT) Mujahidin Pontianak Dengan Menggunakan Fuzzy Inference System Metode Tsukamoto. 